\title{
Studi Ayat-ayat Ekonomi Tentang Al-milk serta Klasifikasi Kepemilikan
}

\author{
Putri Nuraini \\ Universitas Islam Riau \\ Email : putrinuraini@fis.uir.ac.id \\ Rika Septianingsih \\ Email : rikaseptianingsih@umri.ac.id \\ Mohd. Ario Wahdi Elsye \\ Universitas Muhammadiyah Riau \\ Email: ariowahdi@umri.ac.id
}

\begin{abstract}
Human life cannot be separated from economic activities. The existence of a source of Islamic law, namely the Quran, explains various problems in the economic field which contain universal values about how the Islamic economy should be formulated. This research examines and explores the study of economic verses about al-milk and classification of ownership. This research methodology refers to the library approach (library research). This study focuses on the object of study in the form of written theoretical sources regarding al-milk and ownership classification. The results of this study, especially for the academic world, can be used as reference material (literature) which can add to the literature and science, especially in the clumps of Islamic economics and Islamic banking.
\end{abstract}

Keywords : Al-Milk, Economic Verses, Ownership, Classification.

\begin{abstract}
Abstrak
Kehidupan manusia tidak terlepas dari kegiatan ekonomi. Adanya Sumber Hukum Islam yakni Al-Quran menjelaskan berbagai persoalan dalam bidang ekonomi yang memuat nilai-nilai universal tentang bagaimana sebenarnya ekonomi Islam itu harus diformulasikan. Penelitian ini mengkaji dan mendalami studi ayat-ayat ekonomi tentang al-milk serta klasifikasi kepemilikan. Metodologi penelitian ini mengacu kepada pendekatan kepustakaan (library research). Penelitian ini memfokuskan objek kajian berupa sumber-sumber teoritis yang bersifat tertulis mengenai al-milk serta klasifikasi kepemilikan. Hasil dari penelitian ini terutama bagi dunia akademis adalah dapat dijadikan sebagai bahan rujukan (literatur) yang dapat menambah khazanah pustaka dan keilmuan terutama dalam rumpun ilmu bidang ekonomi syariah dan perbankan syariah.
\end{abstract}

\section{PENDAHULUAN}

Alam semesta termasuk manusia adalah milik Allah Subhanahu wa Ta'ala, yang memiliki kemahakuasaan (kedaulatan) sepenuhnya dan sempurna atas makhlukmahkluk-Nya. Manusia tanpa diragukan merupakan tatanan makhluk tertinggi di antara makhluk-makhluk yang telah dicipta-Nya, dan segala sesuatu yang ada dimuka bumi dan di langit ditempatkan dibawah perintah manusia. Dia diberi hak untuk 
memanfaatkan semuanya ini sebagai khalîfah atau pegemban amanat Allah Subhanahu wa Ta'ala. Manusia diberi kekuasaan untuk mengambil keuntungan dan manfaat sebanyak-banyaknya sesuai dengan kemampuannya dari barang-barang ciptaan Allah ini (Akhmad, 2014). Sistem ekonomi Islam adalah penerapan ilmu ekonomi dalam praktik sehari-hari bagi individu maupun kelompok masyarakat dalam rangka mengorganisir faktor produksi, distribusi dan pemanfaatan barang dan jasa yang dihasilkan yangtunduk dalam peraturan/perundang-undangan Islam (Sunnatullah). Sistem ekonomi Islam merupakan sistem ekonomi yang mandiri, bukan bagian sistem ekonomi liberal, komunis, sosialis maupun campuran. Adapun salah satu nilai-nilai dasarnya adalah kepemilikan (Ilfi, 2012).

Menurut M. Umer Chapra (1992), berpendapat bahwa ekonomi Islam diarahkan untuk mewujudkan tujuan syariah (maqoshid syariah) yaitu pemenuhan kebutuhan, penghasilan yang diperoleh dengan sumber yang baik, distribusi pendapatan dan kekayaan yang adil serta pertumbuhan dan stabilitas ekonomi. Sebagai sebuah sistem tersendiri, ekonomi Islam telah menjelaskan segala hal yang berkaitan dengan mekanisme perolehan kepemilikan, tata cara mengelola dan mengembangkan kepemilikan, serta cara mendistribusikan kekayaan tersebut di tengah-tengah manusia secara detail melalui ketetapan hukum-hukumnya. Atas dasar itu, maka hukum-hukum yang menyangkut masalah ekonomi dalam Islam, dibangun atas kaidah-kaidah umum ekonomi Islam (al-qawō'id al-'ammah al-iqtishōdi al-Islōmiyyah) yang meliputi tiga kaidah, yakni : kepemilikan (al-milkiyyah), mekanisme pengelolaan kekayaan (kayfiyyah al-tasarruf fi al-mal) dan distribusi kekayaan diantara manusia (al-tauzil' al-tharwah bayna al-nas) (Akhmad, 2014).

Salah satu prinsip dasar bagi manusia adalah keyakinan bahwa setiap tingkah lakunya adalah cerminan dan manifestasi ibadah kepada Allah Subhanahu wa Ta'ala. Ini berarti bahwa kegiatan ekonomi dan kepemilikan (al-Milk) tidak dapat dipisahkan dengan prinsip tauhid yang mengajarkan kepada manusia bahwa hubungan kepada sesama manusia sama pentingnya dengan hubungan dengan Allah Subhanahu wa Ta'ala. Dalam arti manusia dalam melaksanakan aktivitas ekonominya harus berdasarkan kepada keadilan sosial yang bersumber dari Al-Quran. Sebuah konsep kepemilikan mempunyai landasan yang kuat dari sumber tekstual Islam dengan mendasarkan pada pelacakan kata-kata al-milk baik dalam al-Qur'an maupun al-Hadits. Kata Al-Milk ( الملك ) terhimpun sebanyak 50 Surat dan 106 Ayat dalam Al-Quran (M. Fuad, 1364H). Surat-surat dan ayat-ayat tersebut beserta urutannya dapat dilihat pada tabel 1.1 berikut ini :

Tabel 1.1 Kata-Kata al-Milk dalam Al-Quran

\begin{tabular}{|c|c|c|c|c|c|}
\hline No. & $\begin{array}{l}\text { Wahyu } \\
\text { Orde }\end{array}$ & Surah Nama & Nama Arab & $\begin{array}{c}\text { Ayat-Ayat Yang Terhimpun } \\
\text { Kata Al-Milk }\end{array}$ & $\begin{array}{l}\text { Kelompok } \\
\text { Surat }\end{array}$ \\
\hline 1 & 5 & Al-Fatihah & 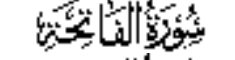 & 4 & Makkiyyah \\
\hline 2 & 10 & Al-Fajar & 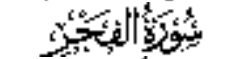 & 22 & Makkiyyah \\
\hline 3 & 21 & An-Nas & 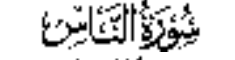 & 2 & Makkiyyah \\
\hline 4 & 23 & An-Najm & (x) & 26 & Makkiyyah \\
\hline 5 & 27 & Al-Buruuj & Bis & 9 & Makkiyyah \\
\hline 6 & 37 & Al-Qamr & 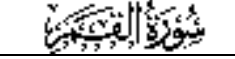 & 55 & Makkiyyah \\
\hline
\end{tabular}




\begin{tabular}{|c|c|c|c|c|c|}
\hline 7 & 38 & Shad & 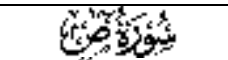 & $10,20,35$ & Makkiyyah \\
\hline 8 & 39 & Al-A'raf & 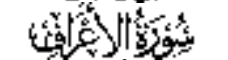 & $158,185,188$ & Makkiyyah \\
\hline 9 & 40 & Al-Jin & 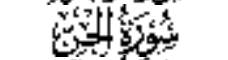 & 21 & Makkiyyah \\
\hline 10 & 41 & Yasin & 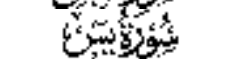 & 71,83 & Makkiyyah \\
\hline 11 & 42 & Al-Furqan & 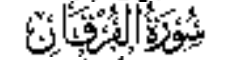 & $2,3,7,26$ & Makkiyyah \\
\hline 12 & 43 & Faathir & Eئ日大 & 13 & Makkiyyah \\
\hline 13 & 44 & Maryam & 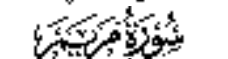 & 87 & Makkiyyah \\
\hline 14 & 45 & $\mathrm{Ta} \mathrm{Ha}$ & بئ日大 & $89,114,120$ & Makkiyyah \\
\hline 15 & 48 & An-Naml & 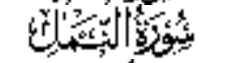 & 23,34 & Makkiyyah \\
\hline 16 & 50 & Al-Isra' & 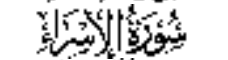 & $56,95,100,111$ & Makkiyyah \\
\hline 17 & 51 & Yunus & 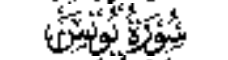 & 31,49 & Makkiyyah \\
\hline 18 & 52 & Hud & $40 \div 306$ & 12,31 & Makkiyyah \\
\hline 19 & 53 & Yusuf & 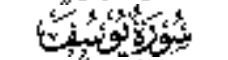 & $31,43,50,54,72,76,101$ & Makkiyyah \\
\hline 20 & 55 & Al-An'am & 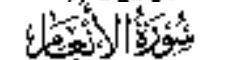 & $8,9,50,73,75$ & Makkiyyah \\
\hline 21 & 58 & Saba' & 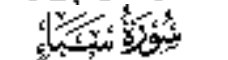 & 22,42 & Makkiyyah \\
\hline 22 & 59 & Az-Zumar & 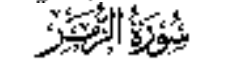 & $6,43,44$ & Makkiyyah \\
\hline 23 & 60 & Ghafir & بئ日大 & 16,29 & Makkiyyah \\
\hline 24 & 62 & Asy-Syuara & بs & 49 & Makkiyyah \\
\hline 25 & 63 & Az-Zukhruf & 420 & $51,85,86,77$ & Makkiyyah \\
\hline 26 & 65 & Al-Jatsiyah & 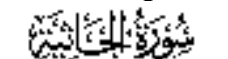 & 27 & Makkiyyah \\
\hline 27 & 66 & Al-Ahqaf & 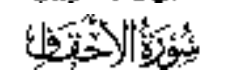 & 8 & Makkiyyah \\
\hline 28 & 69 & Al-Kahfi & 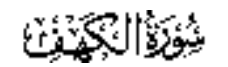 & 79 & Makkiyyah \\
\hline 29 & 70 & An-Nahl & 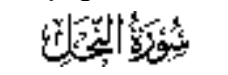 & 73,75 & Makkiyyah \\
\hline 30 & 74 & Al-Mukminun & 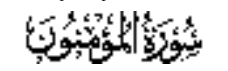 & 88,116 & Makkiyyah \\
\hline 31 & 75 & As-Sajdah & 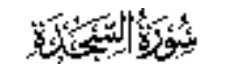 & 11 & Makkiyyah \\
\hline 32 & 77 & Al-Mulk & 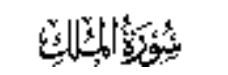 & 1 & Makkiyyah \\
\hline 33 & 78 & Al-Haqqah & بئيقة & 17 & Makkiyyah \\
\hline 34 & 82 & Al-Infitar & 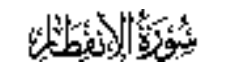 & 19 & Makkiyyah \\
\hline 35 & 85 & Al-Ankabut & 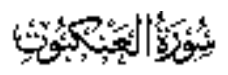 & 17 & Makkiyyah \\
\hline 36 & 87 & Al-Baqarah & 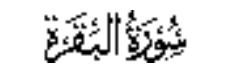 & $102,107,246,247,248,251,258$ & Madaniyah \\
\hline 37 & 89 & Ali Imran & 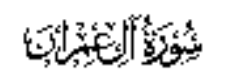 & 26,189 & Madaniyah \\
\hline 38 & 91 & Al-Mumtahanah & 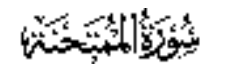 & 4 & Madaniyah \\
\hline 39 & 92 & An-Nisa & 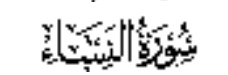 & $17,18,40,53,54,120$ & Madaniyah \\
\hline 40 & 94 & Al-Hadid & 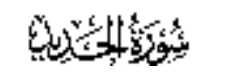 & 2,5 & Madaniyah \\
\hline 41 & 96 & Ar-Ra'd & بئ日大 & 16 & Madaniyah \\
\hline 42 & 98 & Al-Insan & 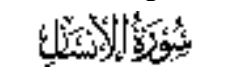 & 20 & Madaniyah \\
\hline 43 & 101 & Al-Hashr & ئ日大 & 23 & Madaniyah \\
\hline 44 & 102 & An-Nur & 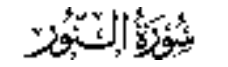 & 42 & Madaniyah \\
\hline 45 & 103 & Al-Hajj & 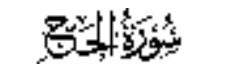 & 56 & Madaniyah \\
\hline 46 & 108 & At-Taghabun & 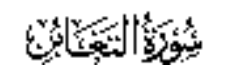 & 1 & Madaniyah \\
\hline
\end{tabular}




\begin{tabular}{|l|l||c|c|c|c|}
\hline 47 & 110 & Al-Jumu'ah & Madaniyah \\
48 & 111 & Al-Fath & 1 & Madaniyah \\
49 & 112 & Al-Maidah & At-Taubah & Madaniyah \\
50 & 113 & At & 11,14 & Madaniyah \\
\hline
\end{tabular}

Sumber Data Olahan, 2020

Karena begitu pentingnya aspek kepemilikan dalam kehidupan sehari-hari khususnya bidang ekonomi, maka perlu adanya penelitian tentang studi ayat-ayat ekonomi berkenaan dengan al-Milk beserta klasifikasi dari kepemilikan tersebut.

\section{PEMBAHASAN}

Prinsip-prinsip dasar ekonomi dalam Al-Quran salah satunya adalah konsep kepemilikan yakni berkeyakinan bahwa setiap tingkah laku manusia adalah cerminan dan manifestasi ibadah kepada Allah Subhanahu wa Ta'ala. Dengan demikian segala aktivitas Muslim tidak terlepas dari hubungan vertikal dengan Allah Subhanahu wa Ta'ala. Implikasi prinsip ini adalah kegiatan ekonomi tidak terlepas dari ibadah kepada Allah. Dengan demikian kekayaan ekonomi harus digunakan untuk memenuhi segala kebutuhan hidup manusia guna meningkatkan pengabdiannya kepaa Allah Subhanahu wa Ta'ala.

Menurut pandangan Islam, harta kekayaan bahkan segala sesuatu adalah milik Allah. Namun demikian diakui pula bahwa potensi manusia dalam mengolah bahan mentah hasil bumi yang telah disiapkan Allah tidak dipungkiri adanya. Hanya saja dalam melaksanakan segala aktivitas itu manusia harus bekerja sama dengan individu lainnya guna keberhasilan usahanya. Maka wajar bila Allah memerintahkan manusia untuk menyisihkan sebagian hartanya untuk kepentingan orang banyak. Mencari, mengumpulkan dan memiliki harta kekayaan tidaklah dilarang selama ia diakui sebagai karunia dan amanah Allah Swt. Alquran tidak menentang kepemilikan harta sebanyak mungkin, bahkan Alquran secara tegas dan berulang-ulang memerintahkan agar berupaya sungguh-sungguh dalam mencari rezeki yang diiistilahkan Alquran dengan "fadhl Allâh" (limpahan karunia Allah Subhanahu wa Ta'ala (Zamakhsyari, 2016).

Al-Quran merupakan sumber pengembangan ajaran Islam dalam berbagai dimensi kehidupan manusia. Untuk melaksanakan pengembangan pemahaman tehadap alQuran dipersyaratkan suatu kualifikasiki kemampuan tertentu guna menghasilkan pemahaman yang baik berbagai aspek kehidupan manusia, termasuk al-milk beserta klasifikasi kepemilikan. Al-Quran dengan keseluruhan ajarannya datang sebagai sumber dan pedoman tingkah laku manusia. Oleh karena tindakan dan tingkah laku ekonomi adalah bagian dari aktivitas manusia maka seluruh kegiatan ekonomi haruslah berada dalam sebuah sistem qurani.

Secara etimologi, kata al-Milk berasal dari bahasa Arab al-milk (الملك) yang berarti milik (Ahmad Warson, 1997). Al - Milk juga berarti sesuatu yang dimiliki (harta). Milik juga merupakan hubungan seseorang dengan suatu harta yang diakui oleh syara', yang menjadikannya mempunyai kekuasaan khusus terhadap harta itu, sehingga ia dapat melakukan tindakan hukum terhadap harta itu, kecuali adanya halangan syara' (Haroen, 2007). Dalam istilah hukum Barat, al-Milk mirip dengan istilah 'ownership' yang berarti "hak milik atau kepemilikan" (John, 1996). 
Secara terminologi, ada beberapa definisi al-milk yang dikemukakan ulama fiqih. Meski demikian, semuanya mengacu kepada makna dan substansi yang sama. Al-Milk adalah :

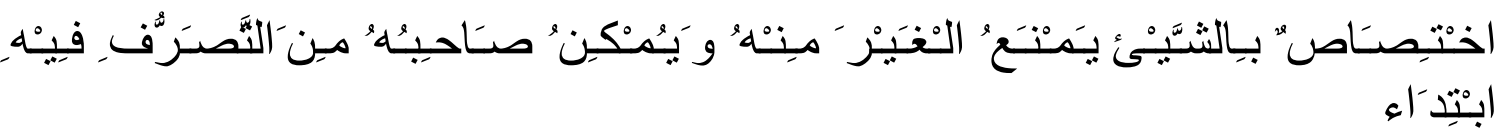

Pengkhususan seseorang terhadap suatu benda yang memungkinkannya untuk bertindak hukum terhadap benda itu (sesuai dengan keinginannya), selama tidak ada larangan syara' (Haroen, 2007).

Menurut Syeikh Hassan Ayob (2008) menyebutkan dalam bukunya bahwa pengertian kepemilikan adalah suatu kekuasaan yang telah ditetapkan syara' untuk menggunakannya kecuali terdapat sebab-sebab yang mencegahnya. Al-Milk juga merupakan kekhususan yang melekat kepada seseorang atas sesuatu, yang orang lain tidak boleh menghalangi untuk memanfaatkan atau menggunakannya kecuali ada penghalang yang berkaitan dengan kecakapan seseorang dalam melakukan tindakan hukum (Ridwan, 2011).

\section{HASIL PENELITIAN}

\section{Studi Ayat-ayat Ekonomi Tentang Al-Milk (Kepemilikan)}

Beberapa surat dan ayat-ayat yang berkaitan dengan al-Milk antara lain adalah sebagai berikut :

Pertama, QS. Ali - Imran (3) ayat 189 tentang Allah Subhanahu wa Ta'ala sebagai pemilik harta secara mutlak.

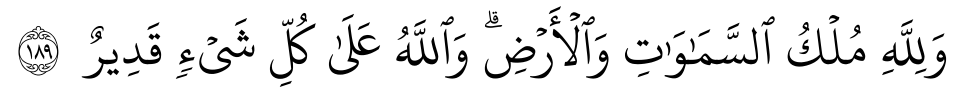

Artinya : "Kepunyaan Allah-lah kerajaan langit dan bumi, dan Allah Maha Perkasa atas segala sesuatu".

Surat Ali-Imran merupakan ayat Madaniyah, karena kebanyakan ayat tersebut sebanyak 83 ayat diturunkan ketika datang utusan dari daerah Najron. Surat Ali-Imran ayat 189 ini secara eksplisit menerangkan bahwa Allah Subhanahu wa Ta'ala sebagai penguasa mutlak dan hakiki atas segala sesuatu. Kekuasaan-Nya sangat luas dan tidak terbatas, mencakup segala sesuatu yang ada di alam semesta ini.

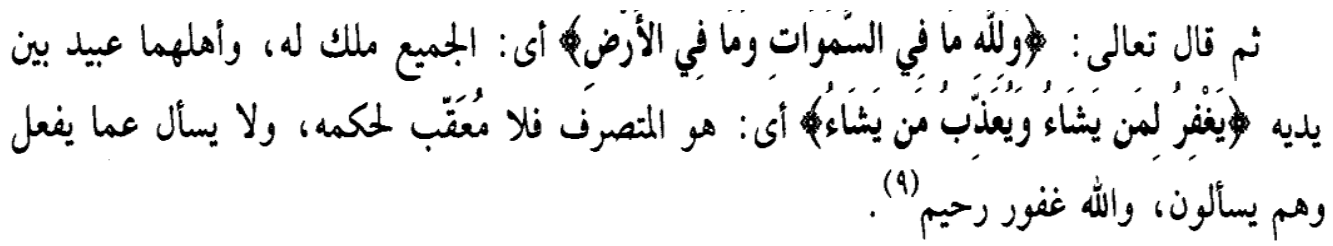

Dalam tafsir Ibn Katsir (1999) tersebut menerangkan bahwa : Allah Subhanahu wa Ta'ala berfirman, "Kepunyaan Allah-lah kerajaan langit dan bumi. Allah Maha Kuasa atas segala sesuatu." Yakni, Dia adalah Yang Memiliki segala sesuatu dan Yang Maha 
Kuasa atas segala sesuau. Maka tidak ada satu perkara pun yang membuat-Nya lemah. Semua perkara tunduk pada-Nya dan tidak menyalahi-Nya. Takutlah kamu terhadap murka dan siksa Allah karena Dialah Yang Maha Agung yang tiada yang lebih agung selain dia, Yang Maha Kuasa yang tiada yang lebih berkuasa selain Dia. Salah satu titik terpenting sistem kepemilikan dalam al-Quran adalah pengakuan bahwa alam semesta berserta isinya adalah milik Allah Subhanahu wa Ta'ala. Kemudian, pemanfaatan isi alam diperuntukkan bagi manusia. Setiap orang berkewajiban untuk mengolah dan mengelola alam semesta. Bahkan, al-Quran memerintahkan setiap individu untuk mencari rezeki guna mencukupi kebutuhan hidupnya.

Allah Subhanahu wa Ta'ala pemilik harta secara mutlak, pemilik (penguasa langit dan bumi. Dia Maha Pencipta dan Pemilik yang hakiki segala sesuatu yang ada di bumi dan seluruh alam semesta. Dia telah menciptakan segala sesuatu untuk kepentingan hidup manusia. Kepemilikan manusia berarti kepemilikan terhadap harta yang didasarkan pada agama, yaitu kepemilikan yang pada dasarnya hanya bersifat sementara, dan bukan menguasai secara mutlakterhadap sumber-sumber produksi, tetapi ia hanya memiliki kemanfataannya (Ilfi, 2012). Semua yang ada di alam semesta ini termasuk sumber daya alam bahkan harta kekayaan yang dikuasai manusia adalah milik Allah Subhanahu wa Ta'ala (QS. Tahaa ayat 6).

Oleh karena itu, manusia sebagai khalifah dibumimaka ia berkewajiban mengelola alam untuk kepentingan umat manusia, dan kelak ia berkewajiban mempertanggungjawabkan pengelolaan sumber daya alam yang dilakukan. Prinsip dasar kepemilikan paling tidak terdapat 2 (dua) yang diungkapkan dalam al-Quran yaitu sebagai berikut:

Pertama, Kepemilikan mutlak hanya dimiliki oleh Allah Subhanahu wa Ta'ala. Hal ini dapat dilihat diantaranya dalam QS. Ali - Imran (3) ayat 189 tersebut diatas dan QS. AlMulk (67) ayat 1 . Sedangkan kepemilikan manusia bersifat relatif. Hal ini dapat dilihat dalam QS. Yasin (36) ayat 71. Berkaitan dengan kepemilikan manusia yang bersifat relatif tersebut, ada beberapa cara yang dilakukan manusia mendapatkan hak kepemilikan, antara lain :

a) Kepemilikan yang berkaitan dengan pemanfaatan sumber daya ekonomi, bukan menguasai sumber daya tersebut. Seorang muslim yang tidak memanfaatkan atau memproduksi manfaat dari sumber-sumber yang diamanatkan Allah tersebut akan kehilangan hak atas sumber-sumber daya itu.

b) Kepemilikan hanya terbatas sepanjang orang itu masih hidup, dan bila orang itu meninggal, maka hak kepemilikannya harus didistribusikan kepada ahli warisnya.

c) Kepemlikan perorangan tidak dibolehkan terhadap sumber-sumber yang menyangkut kepentingan umum atau menjadi hajat hidup orang banyak. Sumbersumber ini menjadi milik umum atau milik negara, tidak dapat dimiliki secara perorangan atau kelompok tertentu.

Kedua, Diperbolehkan mencari, mengumpulkan dan memiliki harta kekayaan selama ia diakui sebagai karunia dan amanah Allah Subhanahu wa Ta'ala. Al-Quran tidak menentang kepemilikan harta sebanyak mungkin, bahkan al-Quran secara tegas dan berulang-ulang memerintahkan agar berupaya sungguh-sungguh dalam mencari rezeki. 


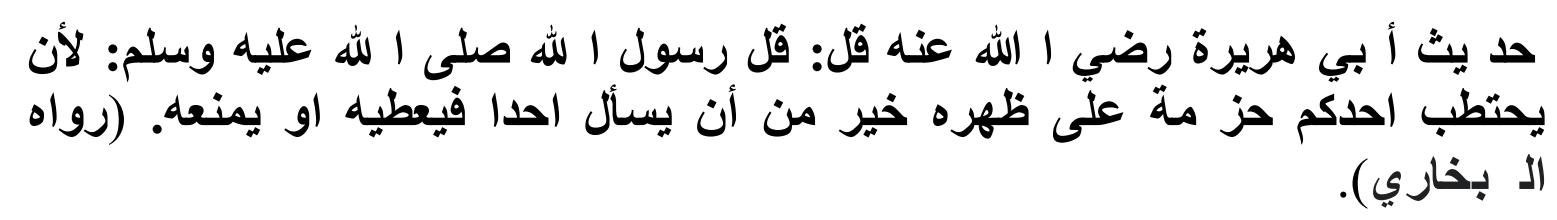

Abu Hurairah r.a berkata: Rasulullah Saw bersabda: "Jika seseorang itu pergi mencari kayu, lalu di angkat seikat kayu di atas punggungnya (yakni untuk di jual di pasar) maka itu lebih baik baginya daripada minta kepada seseorang baik di beri atau di tolak" (Shahih Bukhari dalam Software Maktabah Syamilah) .

Namun yang perlu ditekankan di sini adalah bahwa hak milik dalam Islam pada hakikatnya adalah titipan Allah Subhanahu wa Ta'ala untuk dimanfaatkan dan di distribusikan kepada orang lain dalam batas-batas kedudukan manusia sebagai khalîfah. Sedangkan pemilik mutlak adalah Allah Subhanahu wa Ta'ala. Oleh karena itu, manusia dengan sumber daya alam yang ada mempunyai hak pemanfaatan (haq alintifaq) bukan hak kepemilikan (haq al-tamlik). Dengan menyadari posisi ini, sebagai khalîfah manusia wajib memelihara apa yang ada di alam ini yang berguna untuk kemaslahatan manusia sendiri dan mencegah kerusakan alam yang timbul akibat ulah tangan manusia (Akhmad, 2014).

Kedua, QS. Yasin (36) ayat 71 tentang Allah Subhanahu wa Ta'ala sebagai pencipta hewan ternak

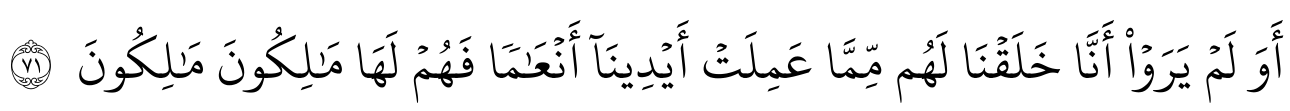

Artinya : "Dan Apakah mereka tidak melihat bahwa Sesungguhnya Kami telah menciptakan binatang ternak untuk mereka Yaitu sebahagian dari apa yang telah Kami ciptakan dengan kekuasaan Kami sendiri, lalu mereka menguasainya?".

Surat Yasin merupakan surat Makkiyah yang agung. Ia berjumlah 83 ayat. Dalam ayat ini Allah memperingatkan kembali kepada kaum kafir tentang sifat dan rahmat yang telah dikaruniakan Nya kepada mereka yang sepatutnya mereka syukuri. Rahmat yang dikaruniakan itu lalu mereka kuasai dan mereka ambil manfaatnya sedemikian rupa. Tetapi mereka tidak pernah bersyukur. Bahkan mengingkari rahmat tersebut.

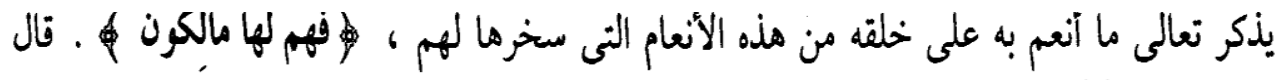

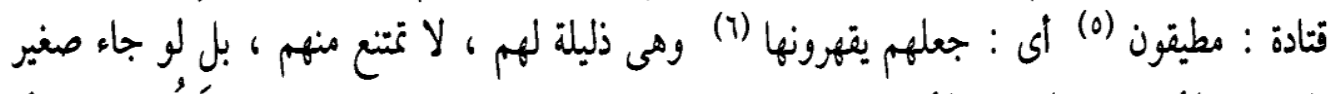

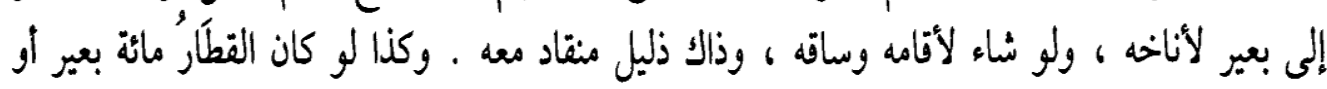

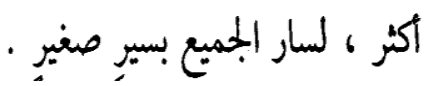

Dalam Tafsir Ibn Katsir (1999), Allah Subhanahu wa Ta'ala menceritakan hewan ternak yang telah ditundukkan bagi mereka sebagai nikmat yang dianugerahkan kepada makhluk-Nya, lalu mereka menguasainya, Yakni : hewan ternak itu patuh dan tidak menolak kehendak manusia. Seandainya iring-irigan seratus unta dituntun oleh anak kecil niscaya semuanya menurut. Allah Subhanahu wa Ta'ala menyebutkan nikmat yang 
telah Ia berikan kepada ciptaan-Nya yaitu berupa hewan ternak yang telah Ia tundukkan kepada mereka. Hewan ternak itu bisa patuh kepada manusia. Hewan ternak itu bisa digembala, karena mereka itu jinak, tidak menolak bahkan seandainya orang kecil pun yang akan menggembalanya maka ia bisa menggembala dan memberi minumnya dan itu menunjukkan bahwa hewan itu jinak dan mau patuh kepadanya. Walaupun jumlahnya sampai 100 ternak atau lebih, mereka bisa berjalan dengan mudah.

Diantara rahmat dart karunia Allah Subhanahu wa Ta'ala adalah bermacammacam hewan dan binatang ternak yang telah diciptakan Allah dan disediakan-Nya untuk manusia. Sebagian dari hewan tersebut mereka jadikan kendaraan untuk mengangkut mereka serta barang-barang dari suatu tempat yang lain. Dan dari hewan itu pula mereka memperoleh bahan makanan, minuman, pakaian dan alat-alat keperluan lainnya. Namun mereka tidak bersyukur kepada Allah Subhanahu wa Ta'ala yang telah menciptakan dan menyediakan semuanya itu untuk kepentingan mereka.

Allah Subhanahu wa Ta'ala telah menciptakan segala sesuatu yang ada di bumi ini untuk kehidupan manusia. Dengan demikian keberadaan manusia di bumi memiliki peran yang sangat besar, yakni memanfaatkan sumber daya alam yang telah disiapkan. Memanfaatkan hasil bumi menjadi bahan makanan untuk melangsungkan hidup dan kehidupan manusia.

Islam menganggap seorang pribadi bagian yang tak terpisahkan dari masyarakat. Oleh sebab itu, pada setiap harta seseorang banyak atau sedikit, ada hak-hak lain yang harus ditunaikan, seperti zakat, sedekah dan nafkah. Hal ini lah yang dimaksudkan Rasulullah Saw dalam sabda beliau :

$$
\text { ان في المال حق سوى الزكاة (رواه الترمدى). }
$$

Artinya : "Sesungguhnya dalam setiap harta itu ada hak-hak orang lain, selain dari zakat. (HR. Sunan at-Tarmidzi dalam Software Maktabah Syamilah).

Kemudian, perlunya kesadaran bahwa harta kekayaan yang bersifat duniawi hakikatnya adalah milik Allah dan sifat kepemilikanya bersifat semu. Artinya, bahwa kepemilikan manusia terhadap hartanya dibatasi oleh dimensi ruang dan waktu. Kepemilikan manusia atas harta beda tidak lebih sebuah amanah (titipan) (al-Qur'an Surat al-Maidah ayat 17).

Ketiga, QS. Al- Mulk (67) ayat 1 tentang Allah Subhanahu wa Ta'ala Maha Kuasa atas segala sesuatu.

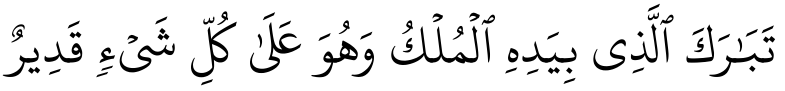

Artinya : "Maha suci Allah yang di tangan-Nyalah segala kerajaan, dan Dia Maha Kuasa atas segala sesuatu".

Dalam ayat ini, Allah Subhanahu wa Ta'ala mengagungkan diri-Nya sendiri dan memberitahukan bahwa kerajaan itu terletak ditangan-Nya. Dialah yang Mengatur semua makhluk-Nya sesuai dengan yang dia kehendaki. Tidak ada yang dapat menolak ketetapan-Nya. Dia tidak akan ditanya tentang perbuatan-Nya, karena Dia adalah 
Mahakuasa, Mahabijaksana, dan Mahaadil. Itulah sebabnya Allah Subhanahu wa Ta'ala berfirman, "Dan Dia Maha Kuasa atas segala sesuatu”.

Maksud dari Maha suci Allah yang menguasai segala kerajaan, dan Dia Maha Kuasa atas segala sesuatu adalah Maha Agung Allah dengan sifat-sifat-Nya dari segala makhluk dan segala sesuatu. Dia kuasa untuk bertindak dalam kerajaan-Nya menurut kehendakNya, memberi nikmat dan menyiksa, mengangkat dan merendahkan memberi dan menahan.

Allah Subhanahu wa Ta'ala memulikan diri-Nya sendiri dan memberitahukan bahwa kerajaan itu terletak ditangan-Nya. Dialah yang mengatur semua makhluk-Nya sesuai dengan yang dia kehendaki. Tidak ada yang dapat menolak ketetapan-Nya dan Dia tidak akan ditanya tentang perbuatan-Nya, karena Dia adalah Mahakuasa, Maha Bijaksana dan maha Adil. Itulah seabnya Allah Ta'ala berfirman, "Dan Dia Maha Kuasa atas segala sesuatu (Muhammad, 2000)".

Ayat diatas jelas bahwa Allah sebagai pencipta alam raya ini. Ayat ini memiliki korelasi (munâsabat ayat) dengan dua ayat sebelumnya yang menyatakan bahwa kepemilikan mutlak hanya dimiliki oleh Allah Subhanahu wa Ta'ala sedangkan kepemilikan manusia bersifat relatif. Oleh karena itu, manusia dituntut untuk dapat bekerja keras demi memenuhi kebutuhan hidupnya dibidang ekonomi. Salah satunya dalam penguasaan hewan ternak untuk diambil manfaatnya.

Ekonomi Islam disebut sebagai ekonomi insani karena sistem ekonomi ini dilaksanakan dan ditujukan untuk kemakmuran manusia. Umer Chapra menyebut sistem ekonomi Islam dengan istilah ekonomi tauhidi. Prinsip dasar ekonomi tauhidi adalah bahwa semua faktor ekonomi termasuk diri manusia pada dasarnya adalah kepunyaan Allah Subhanahu wa Ta'ala.

Kelembagaan tentang pelembagaan hak milik dalam Islam dapat dilihat dalam tulisan Abdul Hameed M. Bashir (2002), "Property Rights, Institutions and Economic Development: An Islamic Perspective" dalam jurnal Humanomic. Inti dari kajian tulisan ini terfokus pada penjelasan urgensi property right untuk dilembagakan dan diakui sebagai institusi ekonomi yang legal. Menurut Abdul Hameed (2002), Negara perlu mebuat regulasi terkait dengan hak kepemilikan harus mendasarkan pada dua nilai etika dasar yaitu 'adl (social-economic justice) dan ihsan (mutual benevolence). Pada bagian akhir dijelaskan praktik-praktik bisnis yang dilarang oleh Syariat.

\section{DISKUSI}

\section{Klasifikasi Kepemilikan (al-Milk)}

Pengakuan dan penghormatan Islam terhadap hak milik telah menempatkan posisi hak milik sebagai salah satu hak dasar manusia yang wajib dilindungi keberadaannya. Mempertahankan hak milik dari upaya orang lain mengambil tanpa alasan yang dibenarkan oleh syari'at merupakan bagian dari kewajiban agama.

Dari beberapa keterangan nash-nash syara' dapat dijelaskan bahwa kepemilikan terklasifikasi menjadi tiga jenis (Akhmad, 2014), yaitu :

Pertama, Kepemilikan Individu/Pribadi (al-milkiyat al-fardhiyah/private property). Kepemilikan Individu/pribadi adalah ketentuan hukum syara' yang berlaku bagi zat ataupun kegunaan tertentu, yang memungkinkan pemiliknya untuk memanfaatkan barang tersebut, serta memperoleh konpensasinya baik karena diambil kegunaannya oleh orang lain seperti disewa ataupun karena dikonsumsi dari barang tersebut. 
Salah satu titik terpenting sistem ekonomi Islam adalah pengakuan terhadap adanya hak milik pribadi. Hak memiiki harta dibolehkan selama digunakan dalam batas-batas kedudukan manusia sebagai khalifah Allah Subhanahu wa Ta'ala. Ungkapan ini cukup beralasan karena adanya prinsip dalam Alquran bahwa Allah Subhanahu wa Ta'ala adalah pemilik yang hakiki.

Ketentuan dasar hak milik individu dalam Islam diakui jika perolehan haknya didapatkan melalui kerjanya sendiri dan bukan diperoleh dengan jalan mengambil hak milik orang lain dan dalam hal hubungannya dengan kepemilikan lahan, yang bukan dari hasil tanamannya sendiri (Ridwan, 2011).

Menurut Ismail dan Arif (2011), hukum syariah menetapkan pula cara atau sebab terjadinya kepemilikan sebagai cara tertentu yang disahkan oleh syariah untuk seseorang memiliki sesuatu yakni:

a) Bekerja.

Islam mendorong manusia bekerja guna mencari karunia Allah Subhanahu wa Ta'ala untuk memenuhi kebutuhan hidup serta menikmati kesejahteraan dan perhiasan dunia. Agar bernilai ibadah, pekerjaan yang dilakukanharuslah sejalan dengan tuntunan syariah sehingga harta yang didapatkan memperoleh berkah.

Alquran telah memberi tuntunan kepada manusia untuk mendapatkan harta, yakni melalui kerja dan usaha yang baik dan halal, tidak dengan jalan yang batil. Larangan memakan harta dengan semua cara yang batil yang tidak diperkenankan Allah Subhanahu wa Ta'ala. Ibn Katsîr (1999) menjelaskan usaha yang dilakukan dengan cara yang batil, tidak sesuai dengan ajaran syariat, seperti judi, penipuan dan riba.

b) Pewarisan.

Waris merupakan suatu mekanisme pembagian harta milik orang yang meninggal kepada ahli warisnya. Berdasarkan ketentuan syariah Islam, ahli waris dapat memiliki harta warisan sebagai ha katas bagian harta waris yang ada. Hukum tentang waris telah dijelaskan secara qath'i (tegas) didalam al-Quran dan as-Sunnah serta Ijmak sahabat. Hukum waris termasuk kategori hukum tawqifi (ketentuan hukum yang bersifat tetap dari Allah Subhanahu wa Ta'ala) tanpa disertai adanya 'illat (sebab ditetapkan hukum) apapun.

c) Kebutuhan akan harta untuk menyambung hidup

Hidup adalah hak setiap manusia. Menjadi hak manusia pula untuk mempertahankan kehidupannya. Salah satunya melalui cara bekerja guna mncukupi segala kebutuhan hidupnya. Oleh karena itu, negara sebagai pelindung dan penjaga rakyat wajib menjamin tersedianya lapangan pekerjaan bagi warga negaranya (Ismail dan Arif, 2011).

d) Pemberian Negara.

Negara dapat memberikan sebagian harta miliknya di Baitul Maal kepada orang yang memerlukan bantuan, baik secara langsung maupun tidak langsung. Bantuan dapat berupa modal kerja, barang modal atau bahkan bahan konsumsi. Misalnya: pertama, negara memberikan sebidang tanah miliknya kepada petani miskin untuk digarap; kedua, atau memberikan modal kerja kepada petani yang mempunyai lahan tetapi tidak mempunyai biaya untuk mengolahnya; ketiga, negara memberikan uang kas kepada rakyat miskin yang banyak berutang. Umar bin al-Khaththab ra. misalnya, pernah memberi para petani di Irak sejumlah harta dari Baitul Maal agar mereka dapat menggarap tanah pertanian serta memenuhi hajat hidup.

e) Harta yang diperoleh tanpa usaha apapun. 
Cara kepemilikan harta seperti ini dapat terjadi dalam berbagai bentuk, antara lain: Pertama, Hibah. Harta bisa didapat seseorang melalui hadiah, hibah, sedekah dan lain-lain dari orang lain yang timbul dari hubungan pribadi antar individu yang mendorong mereka saling memberi dan menolong. Harta yang didapat melalui hadiah, hibah atau wasiat merupakan kepemilikan yang sah secara syar'i. Kedua, Zakat. Bagi orang yang menerima harta zakat, hara itu dia dapatkan tanpa usaha. Ia menerima zakat karena keadaan dirinya yang termasuk salah satu dari kriteria orang yang berhak menerima zakat. Ketiga, Harta kompensasi (diyat). Diyat adalah harta ganti rugi (kompensasi) dari kemhudaratan yang menimpa seseorang, baik berwujud luka, timbulnya disfungsi organ atau hilangnya nyawa. Diyat bisa juga disebut sebagai tebusan yang diberikan oleh pelaku kejahatan kepada penderita atau kepada keluarga yang terbunuh jika mereka tidak mau menuntut qishash. Keempat, Mahar. Mahar dan segala pemberian yang diterima oleh mempelai wanita dari mempelai laki-laki sebagai salah satu rukun nikah. Mahar merupakan bentuk kepemilikan yang sah secara syar'i. Kelima, Luqathah. Barang atau harta temuan seperti emas, perak, permata dan lain-lain, apabila tidak ada yang datang atau tidak ada yang dapat membuktikan bahwa barang atau harta tersebut memang miliknya maka harta temuan tersebut menjadi milik orang yang menemukannya. Keenam, Santuan Negara. Santunan yang diberikan negara kepada para pejabat pemerintahan karena mereka telah meluangkan waktunya untuk melayani rakyat. Meraka bisa memiliki harta itu dengan langsung mengambilnya di Baitul Maal (Ismail dan Arif, 2011).

Dalam menjalankan tugasnya, manusia mendapatkan kekayaan yang menjadi miliknya untuk memenuhi kebutuhan diri beserta keluarganya dan Sebagian lagi untuk kepentingan masyarakat. Meskipun ia memiliki tetapi tidak boleh merusak ataupun menelantarkannya, mengingat kepemilikan ini adalah relatif dan amanah dari Allah Subhanahu wa Ta'ala (Ilfi, 2012). Sekalipun relatif, kepemilikan manusia membawa kewajiban yang harus dipenuhi jika sampai pada batas tertentu untuk membayar zakat. Pada waktu tertentu, kepemilikan tersebut harus diwariskan kepada keluarganya dan juga dapat dipindahkan untuk menjadi barang wakaf.

Kedua, Kepemilikan Umum (al-milkiyyat al-'ammah/public property). Kepemilikan umum adalah ketentuan syariat kepada suatu komunitas untuk bersama-sama memanfaatkan benda, sedangkan benda-benda yang tlah dinyatakan oleh Allah Subhanahu wa Ta'ala sebagai benda-benda yang dimiliki komunitas secara bersamasama dan tidak boleh dikuasai oleh hanya seorang saja atau golongan tertentu. Karena milik umum, maka setiap individu dapat memanfaatkannya namun dilarang memilikinya (Akhmad, 2014).Kepemilikan yang bersifat komunal berlaku pada bendabenda yang mempunyai fungsi-fungsi yang bersifat publik yang proses penguasaannya pada umumnya dilakukan oleh pemerintah. Meskipun kepemilikan kolektif ini diakui sebagai lembaga yang sah, tetapi pemerintah tidak boleh melakukan pengambilalihan hak milik individu menjadi milik umum secara mutlak, akan tetapi harus memenuhi persyaratan-persyaratan yaitu adanya kepentingan umum yang mengharuskannya (Ridwan, 2011).

Sumber-sumber yang menjadi milik umum dapat berupa air, padang rumput, api, garam. Hal tersebut dapat diqiyaskan pada perairan, laut, minyak bumi, hutan, barang tambang, hutan dan udara (Ilfi, 2012). Pemilikan perseorangan tidak boleh menguasai 
sumber-sumber tersebut, karena dikhawatirkan akan terjadi banyak kerusakan. Oleh sebab itu, sumber-sumber yang menyangkut hajat hidup orang banyak lebih baik berada di tangan pemerintah sebagai perwakilan seluruh rakyat. Menurut Ismail dan Arif (2011), benda-benda yang termasuk kedalam kepemilikan umum dapat dikelompokkan menjadi tiga, antara lain: 1) Fasilitas Umum; 2) Bahan tambang yang tidak terbatas. 3) Benda-benda yang sifat pembentukannya menghalangi untuk dimiliki hanya oleh individu.

Ketiga, Kepemilikan Negara (milkiyyat al-daulah/state private). Milkiyyat al-daulah adalah harta yang merupakan hak bagi seluruh kaum muslimin (rakyat) dan pengelolaannya menjadi wewenang khalifah (negara), dimana khalifah (negara) berhak memberikan atau mengkhususkannya kepada sebagian kaum muslimin (rakyat) sesuai dengan ijtihadnya, maka pengelolaan oleh khalifah ini adalah adanya kekuasaan yang dimiliki khalifah untuk mengelolanya (Ridwan, 2011).

Dalam pengertian lain hak milik Negara (al-milkiyyat al-daulah) adalah kepemilikan oleh negara sebagai institusi politik yang berdaulat atas suatu benda. Hak milik Negara juga berarti setiap harta yang penggunaan dan distribusinya menjadi wewenang penuh dari Negara, sepeti harta al-kharraj atau al-jizyah yang penggunaannya ditujukan untuk menciptakan kebaikan bersama (Soerjono, 2003). Meskipun harta milik umum dan milik negara pengelolaannya dilakukan oleh negara, keduanya berbeda. Harta milik umum pada dasarnya tidak boleh diberikan negara kepada siapapun, meskipun negara dapat membolehkan orang-orang untuk mengambil manfaatnya. Adapun terhadap milik negara pemerintah berhak untuk memberikan harta tersebut kepada individu tertentu sesuai dengan kebijakannya. Terhadap minyak, emas, air, tambang, garam, padang rumput, lapangan dan lain-lain, negara tidak boleh sama sekali memberikannya kepada orang tertentu. Adapun harta al-kharraj boleh diberikan kepada para petani saja, sedangkan yang lain tidak, boleh juga dipergunakan untuk membeli senjata saja tanpa dibagikan kepada seorang pun (Ismail dan Arif, 2011).

\section{PENUTUP}

Dari uraian di atas dapat ditarik kesimpulan bahwa banyak ayat-ayat al-Quran yang membicarakan tentang al-milk. Kepemilikan memiliki keterkaitan erat dengan ekonomi Islam. Secara etimologi, kata al-Milk berasal dari bahasa Arab al-milk (الملك) yang berarti milik. Secara terminologi al-milk adalah pengkhususan seseorang terhadap suatu benda yang memungkinkannya untuk bertindak hukum terhadap benda itu (sesuai dengan keinginannya), selama tidak ada larangan syara'. Sebuah konsep kepemilikan mempunyai landasan yang kuat dari sumber tekstual Islam dengan mendasarkan pada pelacakan kata-kata al-milk baik dalam al-Qur'an maupun al-Hadits. Kata Al-Milk terhimpun sebanyak 50 Surat dan 106 Ayat dalam Al-Quran.

Studi ayat-ayat ekonomi tentang al-Milk di antaranya adalah Pertama, QS. Ali Imran (3) ayat 189 adalah Allah Subhanahu wa Ta'ala sebagai pemilik harta secara mutlak. Kedua, QS. Yasin (36) ayat 71 adalah Allah Subhanahu wa Ta'ala sebagai pencipta hewan ternak. Ketiga, QS. Al- Mulk (67) ayat 1 adalah Allah Subhanahu wa Ta'ala Maha Kuasa atas segala sesuatu.

Klasifikasi dari kepemilikan (al-Milk) diantaranya adalah pertama, Kepemilikan Individu / Pribadi (al-milkiyat al-fardhiyah/ private property). Kedua, Kepemilikan Umum (al-milkiyyat al-'ammah/ public property). Ketiga, Kepemilikan Negara (milkiyyat al-daulah/state private). 


\section{DAFTAR PUSTAKA}

Al-Quran Al-Karim

Abdul Hameed M. Bashir. (2002). Property Rights, Institutions and Economic Development: An Islamic Perspective. Humanomic Journal, Volume. 18.

Ahmad Warson Munawwir. (1997). Al-Munawwir Kamus Arab - Indonesia, Surabaya: Pustaka Progressif.

Akhmad Mujahidin. (2014). Ekonomi Islam: Sejarah, Konsep, Instrumen, Negara dan Pasar. Jakarta: Rajawali Pers.

Haroen Nasrun. (2007). Fiqh Muamalah. Jakarta: Gaya Media Pratama, Cet. Kedua.

Ibn Katsir. (1999). Tafsir al-Qur'ān al-Azhim. Riyadh: Dōr Thayyibah. Jilid VI., Cet Ke 2.

Ilfi Nur Diana. (2012). Hadits-Hadits Ekonomi. Malang: UIN-Maliki Press. Cetakan III.

Ismail Yusanto., Arif Yunus. (2011). Pengantar ekonomi Islam. Bogor: Al Azhar Press Cet. 2.

John M. Echols., Hassan Shadily. (1996). Kamus Inggris Indonesia. Jakarta: PT. Gramedia Pustaka Utama.

M. Fuad Al-Baqi. (1364H). Al-Mu'jam Al-Mufahras Li Al-Fazil Quran. Dar Al Kutub Al Mishriyyah.

Muhammad Nasib Ar-Rifa'i. (2000). Kemudahan Dari Allah :Ringkasan Tafsir Ibnu Katsir Jilid 4. Jakarta: Gema Insani Press.

Ridwan. (2011). Hak Milik Perspektif Islam, Kapitalis, dan Sosialis. Yogyakarta: Debut Wahana Press.

Soerjono Soekanto. (2003). Pokok-Pokok Sosiologi Hukum, Jakarta: Raja Grafindo Persada.

Software Maktabah Syamilah.

Syeikh Hassan Ayob. (2008). Fiqh Muamalah. Puchong, Sel.: Berlian Publications SDN. BHD., Cet. Pertama.

M. Umer Chapra. (1992). Islam And The Economic Challage, Leicester: The Islamic Foundation.

Zamakhsyari Abdul Majid. (2016). Ekonomi Dalam Perspektif Al-Quran. Jurnal Ahkam: Vol. XVI, No. 2. 